\title{
PERANCANGAN DAN PERENCANAAN BISNIS TAS YANG DAPAT DIGUNAKAN SEBAGAI LAPTOPPER
}

\author{
Rizal Sukmanagara \\ rizalsukmanagara@gmail.com
}

\begin{abstract}
Abstrak
Masyarakat seringkali memiliki kebiasaan buruk dalam menggunakan Laptop, yaitu menggunakan Laptop diatas bidang yang tidak rata terutama menggunakan Laptop diatas pangkuan. Padahal, menggunakan laptop diatas pangkuan dapat menyebabkan beberapa masalah yang serius diantaranya kulit terbakar dan menurunkan fertilitas. Berdasarkan latar belakang tersebut, maka perlu dibuat sebuah produk dan perencanaan bisnis dari tas yang dapat digunakan sebagai alas Laptop (laptopper) dan juga memiliki tingkat mobilitas tinggi sehingga mudah digunakan dan dibawa kemana-mana tanpa mengganggu aktifitas utama. Penelitian ini menggunakan model deskriptif dalam perancangan produk dan bisnis plan dengan konsep flowchart terhadap pemecahan masalah. Berdasarkan pada penelitian, maka dapat disimpulkan sebagai berikut: Dalam merancang dan menghasilkan tas yang dapat digunakan sebagai alas laptop (laptopper) yang harus dilakukan yaitu mengetahui kebutuhan konsumen, membuat beberapa alternatif rancangan, menganalisa alternatif rancangan, memilih salah satu alternatif rancangan, dan mempresentasikan hasil produk yang telah dikembangkan agar lebih menarik. Dan perencanaan bisnis dari tas yang dapat digunakan sebagai alas laptop (laptopper) harus menganalisis aspek produk, aspek pemasaran, aspek manajemen dan organisasi, dan aspek finansial.
\end{abstract}

Kata-kata kunci: Kewirausahaan, Perancangan Produk, Bisnis Plan.

\begin{abstract}
The community often has a bad habit of using Laptops, that use a Laptop on the uneven field primarily use a Laptop on the lap. In fact, using a laptop on the lap can cause some serious problems such as burning skin and lowers fertility. Based on the background, then it needs to be made a product and business planning of the bag can be used as a Laptop Sockets (laptopper) and also have a high mobility rate so it is easy to use and brought everywhere without interfering with the main activity. This research uses a descriptive model in the design of the product and business plan with the concepts of problem solving flowchart. Based on the research, it can be summed up as follows: in designing and making bags that can be used as a laptop Sockets (laptopper) to do that is to know the needs of consumers, making some alternate drafts, analyzing alternative design, select one of the alternative draft, and presented the results of a product that has been developed to make it more interesting. And business planning of the bag can be used as a laptop Sockets (laptopper) should analyze the aspects of the product, marketing, and management aspects of the Organization, and financial aspects.
\end{abstract}

Key words: Entrepreneurship, Product Design, Business Plan. 


\section{Pendahuluan}

Laptop merupakan pengembangan dari teknologi Komputer Desktop. Dengan menggunakan Laptop masyarakat menjadi lebih dibantu dalam hal mobilitas, karena Laptop dapat dibawa kemana saja sehingga penggunaan teknologi komputer menjadi semakin efektif dan efisien. Namun dalam perkembangannya, masyarakat seringkali memiliki kebiasaan buruk dalam menggunakan Laptop, yaitu menggunakan Laptop diatas bidang yang tidak rata terutama menggunakan Laptop diatas pangkuan. Padahal, menggunakan laptop diatas pangkuan dapat menyebabkan Laptop menjadi cepat panas, sindrom kulit terbakar (toasted skin syndrome), dan untuk pria dapat mengurangi jumlah sperma.

Berdasarkan uraian tersebut, dapat diketahui berbagai masalah yang diakibatkan oleh kesalahan dalam menggunakan Laptop di masyarakat. Sehingga perlu dibuat sebuah produk yang dapat digunakan sebagai alas Laptop (laptopper) dan juga memiliki tingkat mobilitas tinggi sehingga mudah digunakan dan dibawa kemana-mana tanpa mengganggu aktifitas utama. Adapun tujuan yang ingin dicapai dalam pemecahan masalah tersebut adalah merancang dan menghasilkan tas yang dapat digunakan sebagai alas laptop (laptopper). Serta membuat perencanaan bisnis dari tas yang dapat digunakan sebagai alas laptop (laptopper).

\section{Kajian Pustaka}

\subsection{Kewirausahaan}

Menurut Kasmir (2006:19) wirausahawan adalah orang yang berjiwa berani mengambil resiko untuk membuka usaha dalam berbagai kesempatan. Peter F. Ducker dalam Kasmir (2006:20) mengatakan bahwa kewirausahaan merupakan kemampuan dalam menciptakan sesuatu yang baru dan berbeda. Sementara itu, Zimmerer dalam Kasmir (2006:20) mengartikan kewirausahaan sebagai suatu proses pencapaian kreativitas dan inovasi dalam memecahkan persoalan dan menemukan peluang untuk memperbaiki kehidupan (usaha).

Dari beberapa pendapat tersebut dapat disimpulkan bahwa kewirausahaan merupakan suatu kemampuan dalam hal menciptakan kegiatan usaha. Kemampuan menciptakan memerlukan adanya kreativitas dan inovasi yang terus menerus untuk menemukan sesuatu yang berbeda dari yang sudah ada sebelumnya. Kreativitas dan inovasi tersebut pada akhirnya mampu memberikan kontribusi bagi masyarakat banyak.

\subsection{Kreatifitas}

Conny Semiawan dalam Suryana dan Bayu (2011:204) menyatakan: Kreativitas diartikan sebagai kemampuan untuk menciptakan suatu produk baru. Sementara Mc. Pherson dalam Suryana dan Bayu (2011:210) menyatakan bahwa kreativitas adalah menghubungkan dan merangkai ulang pengetahuan didalam pikiran manusia yang membiarkan dirinya untuk berpikir secara lebih bebas dalam membangkitkan hal-hal baru, atau menghasilkan gagasan yang mengejutkan pihak lain dalam menghasilkan hal yang bermanfaat.

Dari beberapa pengertian diatas, kreativitas merupakan sekumpulan ide, baik berupa pengetahuan, maupun pengalaman yang berada dalam pikiran manusia yang kemudian digabungkan menjadi sesuatu hal yang sifatnya kreatif dan berguna baik pada dirinya maupun orang lain atau organisasi dalam situasi atau kondisi yang tidak menentu.

\subsection{Inovasi}

Menurut Panuju (2000:36) Inovasi adalah segala sesuatu tentang ide, cara-cara ataupun objek yang dipersepsikan oleh seseorang sebagai sesuatu yang baru. Menurut Rogers dan Shoemaker dalam Panuju (2000:36) adalah persepsi atau kebaruan yang menentukan reaksinya terhadap hal itu. Jika suatu ide dipandang 
baru oleh seseorang, itulah inovasi. Menurut Suryana dan Bayu (2011:213) Inovasi adalah kreativitas yang diterjemahkan menjadi sesuatu yang dapat diimplementasikan dan memberikan nilai tambah atas sumber daya yang kita miliki.

Jadi, inovasi adalah alat untuk memanfatakan perubahan sebagai peluang bagi bisnis yang berbeda atau jasa yang berbeda. Inovasi dapat ditampilkan sebagai ilmu, dipelajari, dan dipraktikkan. Inovasi juga dikatakan sebagai mengubah nilai dan kepuasan yang diperoleh konsumen dari sumber daya.

\subsection{Produk}

Pengertian produk (product) menurut Kotler dan Keller (2009:4) adalah segala sesuatu yang dapat ditawarkan kepada pasar untuk memuaskan suatu keinginan atau kebutuhan, termasuk barang fisik, jasa, pengalaman, acara, orang, tempat, properti, organisasi, informasi, dan ide. Secara konseptual produk adalah pemahaman subyektif dari produsen atas sesuatu yang bisa ditawarkan sebagai usaha untuk mencapai tujuan organisasi melalui pemenuhan kebutuhan dan kegiatan konsumen, sesuai dengan kompetensi dan kapasitas organisasi serta daya beli pasar. Sedangkan menurut Soegoto E (2009:145) produk adalah segala sesuatu yang bisa ditawarkan kepasar dan dapat memenuhi kebutuhan konsumen.

Berdasarkan definisi-definisi tersebut, dapat disimpulkan bahwa produk adalah segala sesuatu yang dapat ditawarkan kepasar dan memuaskan kebutuhan konsumen, baik berupa barang, jasa, ataupun beragam hal yang ditawarkan.

\subsection{Perencanaan Bisnis}

Hisrich and Peters yang mengatakan bahwa: "The business plan is a written document prepared by the entrepeneur that describe all the relevant external and internal elements involved in starting a new venture." (Hisrich, Peter, 1995:113).
Sedangkan menurut ahli lainnya yaitu Max Coulthard, Andrea Howell, and Geoff.Clarke adalah: "Business plan is a detailed study of the organization's activities, which highlights where the organization has been, where it is owe and where it might get to in the future, and incorporates an action program to achieve these results." (M.Coulthard, A.Howell,G.Clarke, 1999:3).

Jadi perencanaan bisnis/business plan merupakan penelitian mengenai kegiatan organisasi sekarang dan yang akan datang dan menyusun kegiatan untuk mendapatkan hasil yang diinginkan yang dituangkan dalam suatu dokumen perencanaan.

\section{Metode}

Penelitian ini menggunakan model deskriptif dalam perancangan produk dan bisnis plan dengan konsep flowchart terhadap pemecahan masalah. Metode penelitian secara deskriptif adalah metode penelitian yang melakukan penekanan pada pentingnya menghasilkan suatu konsep solusi sejak dini dalam proses perancangan. Sedangkan flowchart digunakan untuk memberikan alur terhadap penelitian telah dilakukan, agar setiap langkahnya saling berhubungan dan bisa saling melengkapi satu sama lain.

Ada dua hal utama yang dilakukan dalam penelitian ini, yang pertama adalah menciptakan sebuah tas yang dapat dijadikan sebagai alas laptop (laptopper) dan yang kedua adalah menciptakan perencanaan bisnis terhadap produk yang telah dibuat agar nantinya dapat dibuat sebuah strategi yang tepat dalam memasarkan produk dan menghasilkan profit bagi pemilik usaha dan investor.

Adapun langkah-langkah yang penulis lakukan dalam melakukan penelitian ini adalah sebagai berikut:

1. Studi lapangan

Studi lapangan dilakukan untuk mengetahui fenomena yang timbul 
akibat penggunaan laptop dan mengumpulkan data-data yang berhubungan dengan penggunaan Laptop yang salah dan upaya-upaya yang dilakukan untuk mengatasi kebiasaan dalam memangku Laptop.

2. Mengidentifikasi masalah

Pada penelitian ini, identifikasi masalah terkait dengan masalah apa saja yang akan timbul dilanjutkan dengan proses perancangan dan pembuatan produk serta perencanaan bisnis yang akan dibuat dalam rangka penciptaan produk yang dapat mengatasi kebiasaan memangku laptop di masyarakat.

3. Menetapkan tujuan penelitian

Didalam penelitian ini, penulis menetapkan tujuan dari penelitian yang ingin dicapai. Yaitu merancang dan menghasilkan tas yang dapat digunakan sebagai alas laptop (laptopper) dan membuat perencanaan bisnis dari tas yang dapat digunakan sebagai alas laptop (laptopper).

4. Studi literatur

Studi literatur dilakukan untuk menemukan teori dan metodologi yang sesuai dengan penelitian yang akan dilakukan.

5. Mengumpulkan data

Pada penelitian ini, data dikumpulkan melalui beberapa teknik pengumpulan data, yaitu menggunakan data primer dan data sekunder. Data primer diperoleh melalui observasi dan wawancara menggunakan kuosioner kepada mahasiswa mahasiswi pada lingkungan kampus UNIKOM, ITB, UNPAD, dan wawancara kepada pembuat tas dan pembuat akrilik untuk memperoleh data bahan dan proses dalam pembuatan tas dan alas laptop. Data sekunder diperoleh dari bukubuku, artikel, dokumentasi, dan referensi lain yang berkaitan dengan masalah yang diteliti sebagai bahan pelengkap dalam melakukan penelitian. Teknik pengumpulan data menggunakan sampel non probabilitas dengan metode Judgement Sampling.
Judgement Sampling merupakan metode yang dilakukan dengan memilih subjek yang memiliki kompetensi tertentu untuk memperoleh informasi yang dibutuhkan (Sekaran and Bougie, 2009:277). Jumlah responden dalam penelitian ini adalah sebanyak 222 responden, responden diperoleh dari metode judgment sampling dengan menggunakan batasan waktu. Waktu yang digunakan untuk menyebarkan kuosioner selama 3 minggu, yaitu masing-masing 1 minggu disetiap Universitas. Dan diperoleh total 222 responden yang terdiri atas:

1. Responden dari UNIKOM sebanyak 74 responden,

2. Responden dari UNPAD sebanyak 80 responden,

3. Responden dari ITB sebanyak 68 responden.

Penyebaran kuosioner dilakukan secara acak kepada mahasiswa/mahasiswi di 3 Perguruan Tinggi di kota Bandung (ITB, UNIKOM, dan UNPAD) yang sedang menggunakan Laptop di lingkungan kampus.

6. Mengolah data

Pengolahan data menggunakan software Microsoft Excel. Dari pengolahan data tersebut diperoleh berbagai macam karakteristik dari keinginan konsumen terkait desain, material, serta harga yang diinginkan konsumen.

7. Perancangan \& pembuatan produk Secara garis besar, proses perancangan produk terdiri dari fase-fase berikut (Ginting, 2010:20).:

1. Langkah pra perancangan produk seperti penetapan asumsi perancangan dan orientasi produk.

2. Langkah Perancangan Produk. Pertama, fase informasi yang dimulai dari mengumpulkan dan menyimpulkan data-data yang diperoleh dari kuosioner dan observasi. Kedua, fase kreatif: Fase Kreatif dimulai dari brainstorming 
berdasarkan informasi yang diperoleh dari fase informasi kemudian mengaplikasikannya kedalam perancangan alternatif desain. Metode brainstorming melibatkan 8 orang anggota yang terdiri atas 5 orang responden, 2 orang pengrajin tas, dan 1 orang pengrajin plastik akrilik. Perancangan produk dilakukan untuk memvisualisasikan dan mengimplementasikan berbagai ide yang diperoleh kedalam gambar sketsa untuk kemudian dibuat kedalam prototype produk. Perancangan produk dilakukan dengan cara sebagai berikut: (a) Membuat sketsa desain awal yang diperoleh dari kuosioner dan brainstorming, (b) Membuat desain akhir dengan menggunakan komputer. Menggunakan software Adobe Illustrator. (c) Mengimplementasikan rancangan yang telah dibuat di komputer. Ketiga, fase analisa: fase ini bertujuan untuk menganalisa alternatif-alternatif yang dihasilkan pada fase kreatif dan memberikan rekomendasi terhadap alternatif-alternatif terbaik. Analisa produk menggunakan konsep Focus Grup Discussion (FGD) yang melibatkan 8 orang terdiri dari 5 orang responden, 2 orang pembuat tas, dan 1 orang pembuat akrilik. Keempat, fase pengembangan: fase ini bertujuan untuk memilih salah satu alternatif tunggal dari beberapa alternatif yang terbaik dan merupakan output dari fase analisa. Data yang dimunculkan yaitu: (a) alternatif terpilih, (b) Gambar produk terpilih dan spesifikasinya. Kelima, fase presentasi: fase ini bertujuan untuk mengkomunikasikan secara baik dan menarik terhadap hasil pengembangan produk.
8. Pembuatan Bisnis Plan

Dalam penelitian ini, langkah-langkah yang dilakukan dalam membuat bisnis plan adalah sebagai berikut:

1. Membuat ringkasan eksekutif

2. Membuat gambaran perusahaan

3. Membuat analisis lingkungan yang terdiri atas analisis lingkungan internal, analisis lingkungan eksternal, analisis situational strategic, analisis potensi dan permasalahan.

4. Membuat analisis produk

5. Membuat rencana pemasaran yang terdiri atas analisa STP dan 7P

6. Membuat rencanan manajemen dan organisasi

7. Membuat rencana kerjasama bisnis

8. Membuat rencana finansial dan analisis kelayakan investasi

\section{Hasil dan Pembahasan}

\subsection{Karakteristik Responden}

\section{Karakteristik Responden Berdasarkan Jenis Kelamin}

Berdasarkan jenis kelamin, sebanyak 58,11 \% atau sebanyak 129 responden berjenis kelamin laki-laki, sisanya sebanyak $41,89 \%$ responden atau sebanyak 93 orang responden berjenis kelamin perempuan. Artinya, mayoritas pengguna laptop di lingkungan kampus berjenis kelamin laki-laki. Laki-laki lebih sering menggunakan laptop di lingkungan kampus untuk browsing dan mengerjakan tugas. Sedangkan perempuan lebih sedikit menggunakan laptop di lingkungan kampus karena faktor kenyamanan. Perempuan merasa kurang nyaman membawa laptop karena bobotnya yang berat, sehingga jarang membawa laptop ke lingkungan kampus.

\section{Karakteristik Responden} Berdasarkan Jenis Kelamin

Berdasarkan umur, mayoritas pengguna laptop berada pada umur 
18, 19, 20, dan 21 tahun. Dengan presentase masing-masing $20,27 \%$ (45 responden), 20,27\% (45 responden), 21,62\% (48 responden), dan $18,02 \%$ (40 responden). Sedangkan untuk responden yang paling sedikit menggunakan laptop adalah umur 26 - 30 tahun, yaitu sebanyak 4 responden atau sebanyak 2,25\%. Kisaran umur pengguna laptop di lingkungan kampus yaitu dari $18-21$ tahun. Hal tersebut karena mayoritas mahasiswa dan mahasiswi yang kuliah di perguruan tinggi berada di umur $18-21$ tahun atau setara dengan jenjang pendidikan Strata 1.

\subsection{Deskriptif Pertanyaan penelitian}

1. Menggunakan Laptop diatas Pangkuan

Mayoritas responden menggunakan laptop diatas pangkuan. Menggunakan laptop diatas pangkuan menjadi sebuah kebiasaan karena dianggap lebih efisien. Sedangkan responden yang tidak pernah menggunakan laptop diatas pangkuan beralasan karena khawatir dapat menurunkan fertilitas pria.

2. Durasi menggunakan laptop diatas pangkuan

Mayoritas para pengguna laptop menggunakan laptop diatas pangkuan selama 1-60 menit. Hal tersebut karena menggunakan laptop diatas pangkuan dilakukan pada situasi tertentu saja, pada saat lingkungan tidak mendukung untuk menggunakan laptop di atas meja atau lantai.

3. Merasakan kesulitan ketika menggunakan laptop diatas pangkuan

Mayoritas para pengguna laptop merasakan kesulitan ketika menggunakan laptop diatas pangkuan. Kesulitan tersebut muncul karena laptop menghasilkan panas berlebih, tidak ada bidang datar yang dapat dijadikan alas, dan terlalu lama memangku laptop juga mengurangi kenyamanan tubuh.

4. Keluhan yang paling sering dirasakan ketika menggunakan laptop diatas pangkuan

Mayoritas para pengguna laptop merasakan panas berlebih yang dikeluarkan oleh laptop ketika menggunakan laptop diatas pangkuan, hal tersebut karena laptop mengeluarkan panas sekitar 40 $60 \mathrm{oC}$ sehingga pemakaian laptop yang langsung diatas pangkuan akan menyebabkan panas dan terbakar.

5. Pengetahuan terhadap produk alas laptop (laptopper)

Mayoritas pengguna laptop tidak mengetahui ada produk yang bernama laptopper yang biasa digunakan sebagai bantalan ketika menggunakan laptop diatas pangkuan. Laptopper merupakan produk baru yang kurang dipromosikan sehingga keberadaannya kurang diketahui para pengguna laptop.

6. Kelemahan laptopper

Mayoritas pengguna laptop tidak menyukai ukuran laptopper yang terlalu besar, karena bentuk yang besar mengurangi kenyaman dan kemudahan dalam penggunaan. Ukuran laptopper yang paling kecil adalah $30 \mathrm{~cm} \mathrm{x} 40 \mathrm{~cm}$ ukuran tersebut dirasa terlalu besar jika ingin dibawa keluar rumah.

7. Bahan alas laptop yang diinginkan konsumen

Mayoritas pengguna laptop menginginkan bahan alas dari plastik karena plastik lebih ringan sehingga mudah dibawa. Sedangkan bahan aluminium dan kayu dianggap lebih berat dan sulit dibawa dalam aktivitas sehari-hari. 
8. Bentuk tas laptop yang dibutuhkan konsumen

Mayoritas pengguna laptop menginginkan tas yang di gendong (ransel) karena lebih mudah digunakan dan dapat mengurangi beban yang berat dari laptop. Tas model ransel menggunakan 2 buat selendang, sehingga berat laptop akan dibebankan pada pundak melalui kedua selendang dan mengurangi beban yang berlebih ketika digunakan sehingga meningkatkan kenyamanan. Sedangkan untuk tas model selendang, akan terasa lebih berat ketika membawa laptop. Karena beban akan tertumpu pada satu bagian pundak, sehingga penggunaan jangka panjang akan mengurangi kenyamanan.

9. Jenis bahan tas yang diinginkan Mayoritas pengguna laptop menginginkan tas yang memiliki bahan yang lembut. Bahan yang lembut akan meningkatkan kenyamanan ketika digunakan sehingga mengurangi beban ketika membawa laptop.

10. Warna tas laptop yang diinginkan Mayoritas pengguna laptop menginginkan tas yang berwarna gelap. Tas yang berwarna gelap lebih disukai karena tidak terlalu menarik perhatian, selain itu tas berwarna gelap lebih terlihat eksklusif dibandingkan tas berwarna cerah.

11. Desain tas laptop yang diinginkan Mayoritas pengguna laptop menginginkan tas yang ekslkusif. Tas yang eksklusif akan menimbulkan kesan khusus sehingga tas yang dimiliki tidak akan dimiliki oleh orang lain dan akan meningkatkan kepuasan para pemilik tas.
12. Kisaran harga yang diinginkan

Mayoritas pengguna laptop menginginkan kisaran harga 200 300 ribu rupiah, hal tersebut karena segmen para pengguna laptop adalah pelajar sehingga memiliki keterbatasan uang. Oleh karena itu, segmen pelajar lebih memilih untuk kisaran harga yang paling rendah yang terjangkau oleh mereka.

13. Bersedia dihubungi untuk melakukan testing

Mayoritas pengguna laptop tidak bersedia memberikan nomor teleponnya. Para pengguna laptop enggan memberikan nomor teleponnya karena ketakutan nomornya akan disalah gunakan oleh orang yang tidak berkepentingan.

\subsection{Perancangan dan Pembuatan Produk}

\subsubsection{Fase Informasi}

Tabel kriteria kebutuhan konsumen

\begin{tabular}{|c|l|l|}
\hline No & Informasi & Keterangan \\
\hline 1 & Bentuk tas & $\begin{array}{l}\text { Gendong } \\
\text { (ransel) }\end{array}$ \\
\hline 2 & Desain Tas & $\begin{array}{l}\text { Simpel dan } \\
\text { Elegan }\end{array}$ \\
\hline 3 & Bahan Tas & Lembut \\
\hline 4 & Warna Tas & Gelap \\
\hline 5 & $\begin{array}{l}\text { Bahan Alas } \\
\text { Laptop }\end{array}$ & Plastik \\
\hline
\end{tabular}

\subsubsection{Fase Kreatif}

Alternatif 1:

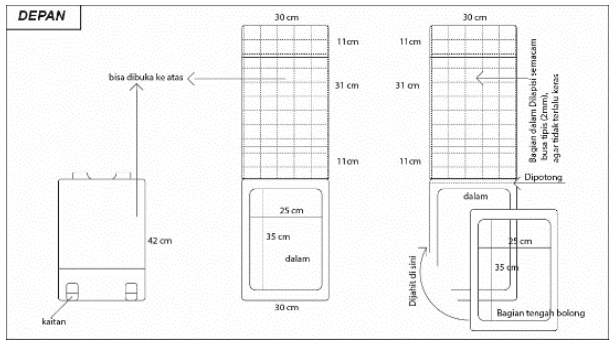




\section{BIDANG MANAJEMEN}

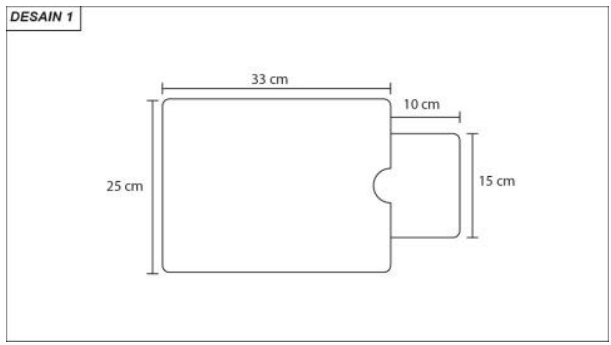

\subsubsection{Fase Analisa}

Analisa Alternatif 1

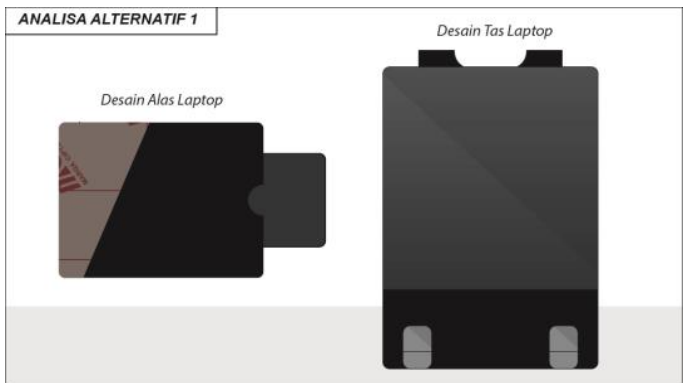

Alternatif 2

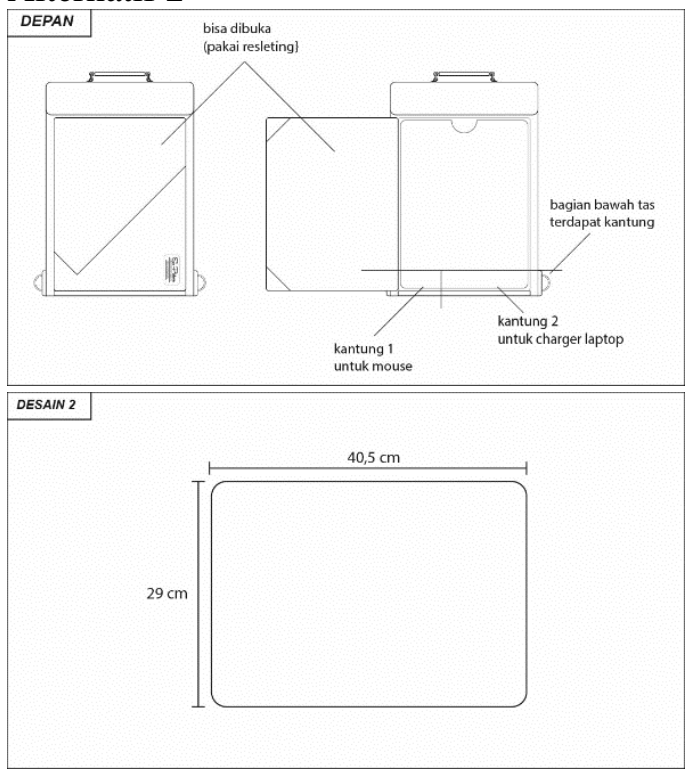

Alternatif 3

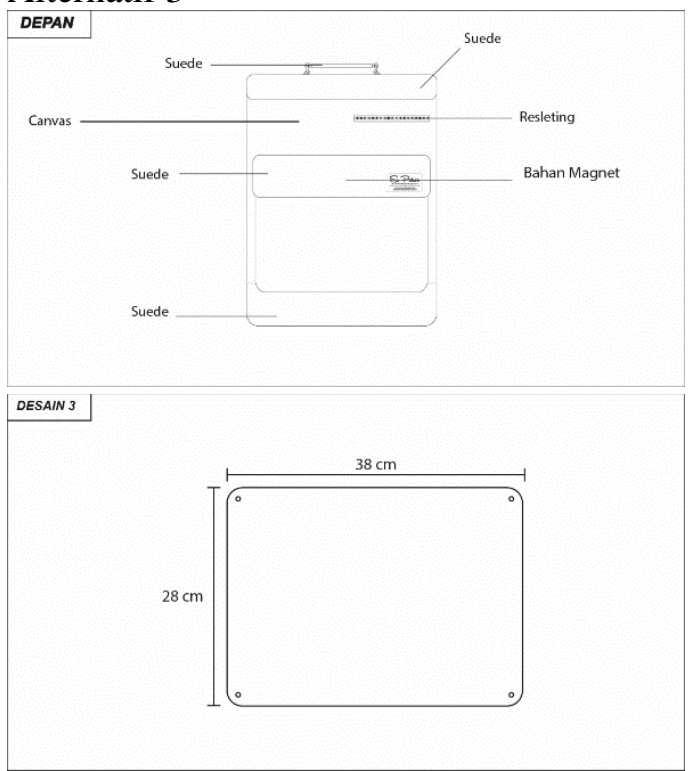

Desain Tas Alternatif 1:

- Desain tas lebih sederhana,

- Bahan menggunakan kain 600D,

- Bentuk tas terlalu besar dan tidak dinamis,

- Bahan tas kurang lembut,

- Agak sulit ketika hendak menggunakan laptop diatas pangkuan,

- Tas lebih ringan.

- Pooring tidak menjangkau seluruh sisi

Desain Alas Alternatif 1:

- Menggunakan model slide untuk alas

Mouse dan Hardisk

- Ukuran alas terlalu kecil,

- Penggunaan model slide harus lebih dipikirkan kemudahan penggunaannya

- Sulit diaplikasikan pada tas

- Biaya produksi terlalu mahal

\section{Analisa Alternatif 2}

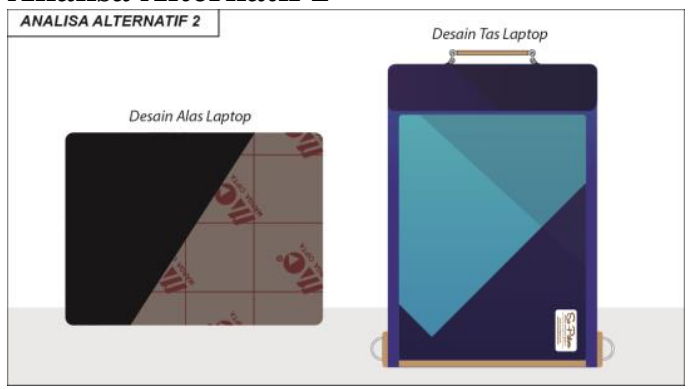

Desain Tas Alternatif 2:

- Desain tas lebih sederhana,

- Bahan menggunakan kain Denim,

- Bahan menyerap air sehingga tas tidak dapat digunakan saat hujan tiba,

- Bentuk tas terlalu kecil,

- Penggunaan resleting terlalu besar,

- Bahan nyaman digunakan,

- Lebih mudah ketika menggunakan tas diatas pangkuan,

- Tas lebih ringan. 
Desain Alas Alternatif 2:

- Lebih sederhana

- Ukuran terlalu besar

- Terlalu berat

- Tidak mudah digunakan

- Mudah diaplikasikan kedalam tas

\section{Analisa Alternatif 3}

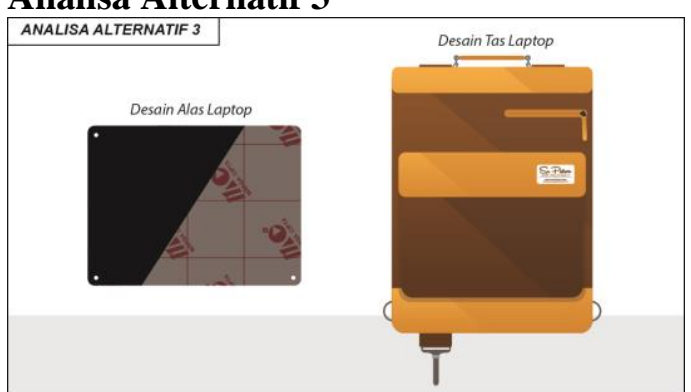

Desain Tas Alternatif 3:

- Desain tas lebih sederhana (eksklusif),

- Bahan menggunakan kain Canvas dan

Suede,

- Bahan tas lembut

- Lebih mudah digunakan

- Tas lebih ringan

- Lebih nyaman ketika digunakan, karena menggunakan alas dari kain Double Mess yang dilapisi busa,

- Full Pooring, sehingga anti air.

Desain Alas Alternatif 3:

- Memiliki ukuran yang tidak terlalu besar,

- Tidak terlalu berat

- Memiliki lubang yang berfungsi meletakan kancing agar mudah diaplikasikan dalam tas,

- Desain yang lebih sederhana sehingga mudah digunakan

\subsubsection{Fase Pengembangan}

Alternatif yang terpilih berdasarkan hasil FGD adalah alternatif 3 , alternatif 3 menggunakan bahan kain canvas, kulit suede, dan kain double mas. Untuk material alas laptop (laptopper), menggunakan jenis plastik akrilik. Plastik akrilik dipilih karena lebih ringan dan lebih tahan benturan, tidak beracun dan tahan terhadap reaksi kimia dibanding bahan plastik lainnya, tidak berkerut dan berubah warna, tidak bereaksi terhadap sinar matahari, tahan terhadap cuaca luar, serta dapat didaur ulang.

Adapun gambar dan spesifikasinya adalah seperti Gambar berikut:

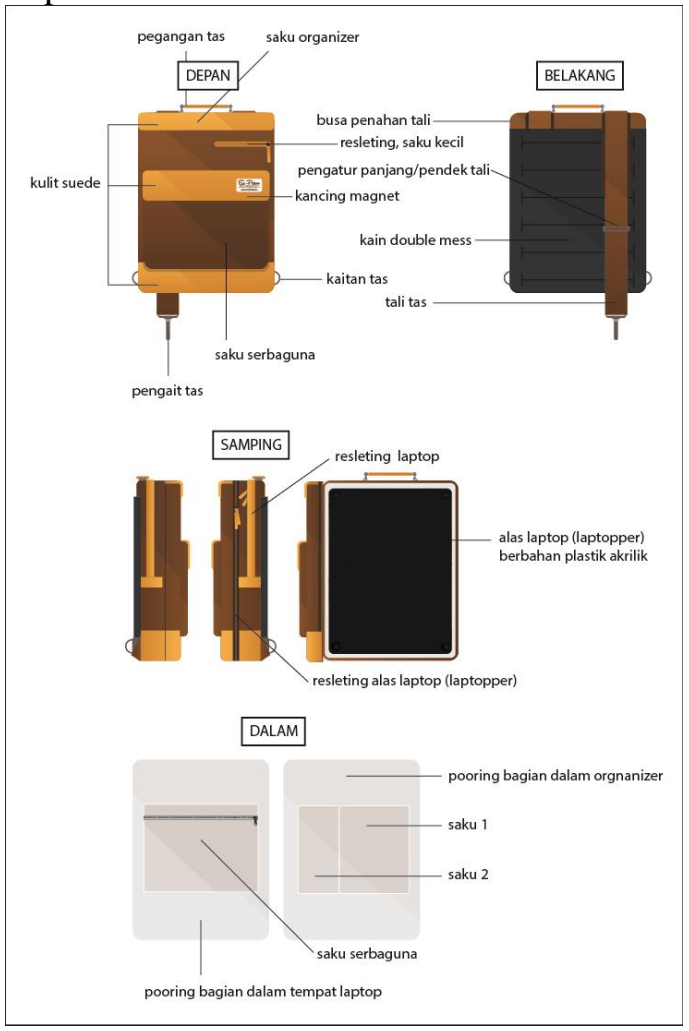

\subsubsection{Fase Presentasi}

Tas memiliki desain yang eksklusif dengan warna cokelat tua. Bahan utama yang digunakan adalah bahan kain canvas yang memiliki ketahanan dan warna yang menarik, ditambah dengan kulit suede sehingga menambah kesan eksklusif, untuk bagian belakang ditambahkan kain jenis double mess agar meningkatkan kenyamanan Dalam penggunaannya, tas dipakai seperti tas pada umumnya, namun tas memilik laptopper yang dapat digunakan sebagai alas laptop ketika tidak ada meja atau bidang datar yang dapat dipakai alas. Tas dapat digunakan ketika duduk dikursi atau ketika di tempat tidur.

\subsection{Pembuatan Bisnis Plan}

\subsubsection{Ringkasan Eksekutif}

Meningkatnya pengguna laptop di Indonesia, terutama untuk segmen pelajar dan mahasiswa menciptakan kebiasaan baru 


\section{BIDANG MANAJEMEN}

di kalangan mahasiswa, yaitu membawa laptop di lingkungan kampus. Penggunaan laptop di lingkungan kampus juga seringkali kurang tepat. Yaitu menggunakan laptop diatas pangkuan. Padahal, ada beberapa kelemahan dari kebiasaan memangku laptop diatas pangguan.

Berdasarkan latar belakang tersebut, maka diciptakanlah sebuah tas inovatif yang dapat dijadikan alas laptop (laptopper) untuk segmen pelajar dan mahasiswa. Tas yang diciptakan sesuai dengan keinginan segmen yang dituju, dengan desain yang sederhana namun tidak mengurangi nilai guna dari produk menciptakan sebuah perpaduan tas yang fashionable dan memiliki nilai guna tinggi bagi segmen anak muda yang memiliki mobilitas tinggi.

Promosi bisnis ini dikembangkan dengan model bisnis online yang sesuai dengan segmentasi anak muda untuk menjaring para distributor dan konsumen dari kalangan anak muda, serta menggunakan berbagai media yang sering digunakan oleh anak muda dalam berbagai interaksi kesehariannya.

Peluang yang dihasilkan dari bisnis tas laptop inovatif ini masih terbuka lebar, berdasarkan observasi yang dilakukan selama 3 bulan, belum ada produk (tas) yang dapat digunakan sebagai laptopper sehingga bisnis ini akan menghasilkan keuntungan yang besar. Dengan investasi yang dikeluarkan pada tahun pertama sebesar Rp 153.000.000,- dalam kurun waktu 3 tahun, keuntungan yang diperoleh sebesar $\mathrm{Rp}$ 810.918.000,- dan nilai pengembalian investasi hanya selama 1 tahun 9 bulan sehingga bisnis ini merupakan bisnis yang memiliki prospek yang cemerlang.

\subsubsection{Analisis Lingkungan} Analisis Lingkungan Eksternal

\section{Opportunities (Peluang)}

1. Meningkatnya pengguna laptop di Indonesia

2. Kesadaran masyarakat akan bahaya memangku laptop
3. Belum ada tas yang secara khusus dapat digunakan sebagai alas laptop

4. Gaya hidup remaja indonesia yang konsumtif dan up to date

5. Meningkatnya pendapatan perkapita rakyat Indonesia

Threads (Ancaman)

1. Pembajakan yang merajalela

2. Kenaikan harga bahan baku

3. Perkembangan teknologi komputer laptop

4. Tekanan dari produsen besar dengan strategi cost leadership

5. Perubahan tren fashion tas dunia

\section{Analisis Lingkungan Internal}

\section{Strenghts (Kekuatan)}

1. Produk tas yang inovatif dan fungsional

2. Desain yang sesuai dengan segmentasi anak muda

3. Harga yang dapat bersaing

4. Pelayanan yang memuaskan

5. SDM yang tangguh

Weakness (Kelemahan)

1. Pengembangan produk yang masih berjalan

2. Manajerial timeline produksi

3. Keterbatasan anggaran produksi dan promosi

4. Pengembangan Branding Image

5. Kontrol yang lemah terhadap kualitas barang

Matriks SWOT

\begin{tabular}{|c|c|c|}
\hline Internal Factors & $\begin{array}{l}\text { Strenghts } \\
\text { S1. Produk inovatif } \\
\text { S2. Desain sesuai segmen anak } \\
\text { muda } \\
\text { S3. Harga harga murah } \\
\text { S4. Pelayanan memuaskan } \\
\text { S5. SDM yang tangguh \& } \\
\quad \text { Berkualitas }\end{array}$ & $\begin{array}{l}\text { Weakness } \\
\text { W1. Pengembangan produk } \\
\text { W2. Manajerial timeline } \\
\text { produksi } \\
\text { W3. Anggaran produksi dan } \\
\text { promosi } \\
\text { W4. Pengembangan Branding } \\
\text { Image } \\
\text { W5. Kontrol yang lemah }\end{array}$ \\
\hline $\begin{array}{l}\text { Opportunities } \\
\text { O1. Meningkatnya pengguna } \\
\text { laptop } \\
\text { O2. Kesadaran akan bahaya } \\
\text { memangku laptop } \\
\text { O3. Belum ada tas yang secara } \\
\text { khusus dapat digunakan } \\
\text { sebagai alas laptop } \\
\text { O4. Gaya hidup konsumtif dan } \\
\text { up to date } \\
\text { O5. Meningkatnya pendapatan } \\
\text { perkapita rakyat Indonesia }\end{array}$ & $\begin{array}{l}\text { SO Strategies } \\
\text { S1O1 Promosi di event-event } \\
\text { pameran laptop. } \\
\text { S1O2 Promosi di event-event } \\
\text { Kesehatan. } \\
\text { S2O4 Desain yang selalu } \\
\text { berganti (uptodate). } \\
\text { S3O5 Perluasan pasar. } \\
\text { S4O3 Fast respond dalam } \\
\text { menanggapi berbagai } \\
\text { pertanyaan. }\end{array}$ & $\begin{array}{l}\text { WO Strategies } \\
\text { W4O2 Penciptaan branding } \\
\text { image tentang tas yang } \\
\text { sehat } \\
\text { W3O4 Optimalisasi media } \\
\text { sosial untuk promosi } \\
\text { W105 Percepatan penjualan } \\
\text { sehingga siklus hidup } \\
\text { produk berlangsung } \\
\text { cepat }\end{array}$ \\
\hline $\begin{array}{l}\text { Threads } \\
\text { T1. Pembajakan } \\
\text { T2. Kenaikan harga bahan baku } \\
\text { T3. Perkembangan teknologi } \\
\text { laptop } \\
\text { T4. Tekanan strategi cost } \\
\text { leadership pesaing } \\
\text { T5. Perubahan tren tas }\end{array}$ & $\begin{array}{l}\text { ST Strategies } \\
\text { S3T4 Harga murah diikuti } \\
\text { dengan kualitas } \\
\text { S2T5 Desain tas yang terus di } \\
\text { update } \\
\text { S1T3 R\&D pada tas yang } \\
\text { lebih inovatif } \\
\text { S4T2 Meningkatkan kualitas } \\
\quad \text { pelayanan }\end{array}$ & $\begin{array}{l}\text { WT Strategies } \\
\text { W1T2 Menciptakan produk } \\
\quad \text { yang berkualitas } \\
\text { W4T1 Mendaftarkan HaKi } \\
\text { W3T4 Menjalin komunikasi } \\
\quad \text { yang baik dengan } \\
\text { produsen dan pesaing }\end{array}$ \\
\hline
\end{tabular}


Analisis Situational Strategic

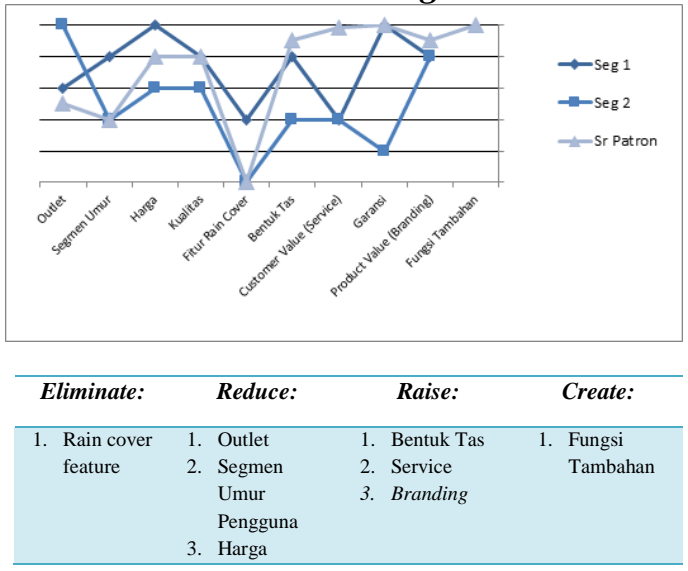

\section{Analisis Potensi dan Permasalahan}

1. Proses produksi yang tidak tepat waktu Dikarenakan proses produksi dilimpahkan kepada konveksi tas (vendor) lain, maka ada kemungkinan keterlambatan produksi yang tidak sesuai jadwal. Hal tersebut tergantung kepada pengelolaan sistem manajerial dari vendor.

Masalah tersebut dapat diatasi dengan melakukan kontrol yang ketat terhadap vendor serta komunikasi yang berkelanjutan agar setiap masalah yang timbul di vendor dapat segera dilakukan pemecahannya secara cepat.

2. Pembajakan

Masalah yang sering timbul adalah pembajakan, ketika sebuah produk dapat mendatangkan profit yang besar, para pengusaha yang tidak bertanggung jawab sering kali membuat duplikat dari produk tersebut, pembajakan saat ini bahkan buka dalam produknya saja, tetapi sudah merambah kedalam merek dagang.

Masalah tersebut dapat diatasi dengan cara segera mendaftarkan HaKi terhadap paten terhadap dan merk terhadap produk ini. Pendaftaran paten dan merk harus dilakukan sedini mungkin untuk menghindari pembajakan yang marak di Indonesia. Selain dengan mendaftarkan $\mathrm{HaKi}$, strategi yang dilakukan adalah meluncurkan tas baru yang lebih inovatif, sehingga ketika banyak perusahaan yang membuat produk serupa, kita sudah selangkah lebih maju kedepan dengan menciptakan inovasi baru yang belum penah diciptakan sebelumnya.

3. Kenaikan harga bahan baku

Kenaikan bahan baku dapat diatasi dengan menaikan harga tas, kenaikan harga tas dilakukan secara berkala dan sedikit demi sedikit.

\subsubsection{Analisis Produk}

Merk Produk : Sr Patron

Jenis Produk : Tas Laptop dengan model gendong (ransel)

Dimensi Produk: Panjang $=10 \mathrm{~cm}$ Lebar $=$ $29 \mathrm{~cm}$ Tinggi $=45 \mathrm{~cm}$

Bahan Produk : Kain Canvas, Kain Suede, Kain Double Mess,dan bahan pelengkap tas lain.

Keunggulan Produk : Inovasi Fungsi Alas Laptop, Kualitas bahan pilihan, Desain yang sesuai segmen pelajar

\subsubsection{Rencana Pemasaran}

\section{Analisis STP}

\section{Segmen Pasar}

1. Geografis: Wilayah Indonesia

2. Demografi: Umur $18-21$ tahun terutama mahasiswa dan pelajar

3. Psikologis: Mahasiswa dan pelajar kelas menengah dengan pendapatan kurang lebih Rp 2.000.000 per bulan, menyukai gadget, teknologi, dan peduli terhadap kesehatan.

Target

1. Konsentrasi Produk: Mahasiswa dan pelajar aktif yang selalu menggunakan laptop. Terutama mereka yang memiliki kebiasaan menggunakan laptop diatas pangkuan.

2. Spesialisasi Produk : Tas yang dapat digunakan sebagai alas laptop (laptopper)

\section{Positioning}

Positioning perusahaan terletak pada inovasi pengembangan fungsi tas, yaitu tas yang dapat digunakan sebagai tas laptop, 


\section{BIDANG MANAJEMEN}

dimana pesaing belum melakukan hal tersebut. Selain itu, perusahaan mengusung konsep desain tas yang sederhana namun memiliki kemudahan dalam penggunaaan. Citra yang dimunculkan di benak konsumen yaitu inovasi fungsi, desain, dan kualitas

\section{Strategi Bauran Pemasaran}

\section{Produk,}

Tas fashionable yang dapat digunakan sebagai alas laptop (laptopper).

2. Price

Rp 290.000,-

3. Place

Online, authentic distributor, dan outlet

4. Promotion

Internet advertising dan sales promotion (outlet dan authentic distributor).

5. People

Brand ambassador dan anak muda yang menyukai gadget

6. Process

Pelayanan yang memuaskan (fast respond), pengiriman tepat waktu.

7. Physical Evidence

Website dan outlet dengan konsep simply design.

\subsubsection{Rencanan Manajemen Organisasi}

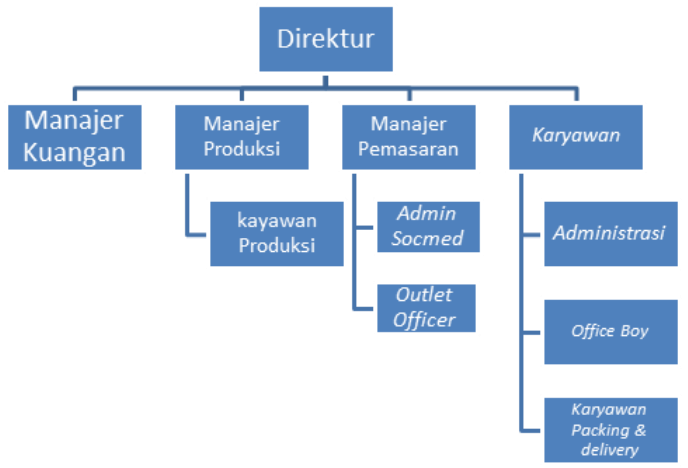

\begin{tabular}{|c|c|c|c|l|}
\hline \multirow{2}{*}{ No } & \multicolumn{2}{|c|}{$\begin{array}{c}\text { Jumlah } \\
\text { Tahun Ke }\end{array}$} & \multicolumn{2}{c}{ Jabatan } \\
\cline { 2 - 4 } & I & II & III & \\
\hline 1 & 1 & 1 & 1 & Direktur \\
\hline 2 & 1 & 1 & 1 & Manajer Keuangan \\
\hline 3 & - & - & 1 & Manajer Produksi \\
\hline 4 & - & - & 4 & Karyawan Produksi \\
\hline 5 & 1 & 1 & 1 & Manajer Pemasaran \\
\hline 6 & 1 & 1 & 1 & Administrasi \\
\hline
\end{tabular}

\begin{tabular}{|c|c|c|c|l|}
\hline 7 & 3 & 5 & 7 & Admin Social Media \\
\hline 8 & - & 2 & 4 & Outlet Officer \\
\hline 9 & 1 & 2 & 4 & $\begin{array}{l}\text { Karyawan (Packing \& } \\
\text { Delivery) }\end{array}$ \\
\hline 10 & 1 & 1 & 1 & Office Boy \\
\hline
\end{tabular}

4.4.6. Rencana Kerjasama Bisnis

Kerjasama bisnis yang akan dilakukan yaitu menambah jumlah outlet yang akan bekerjasama dengan para investor. Dan merger dengan konveksi pembuat tas (vendor) agar dapat mempermudah kontrol produksi dan mempercepat proses produksi tas.

\subsubsection{Rencana Finansial}

\begin{tabular}{|l|l|lr|}
\hline \multirow{4}{*}{ Modal Kerja Awal } & Investasi Awal & $\mathrm{Rp}$ & 90.500 .000 \\
\cline { 2 - 4 } & Biaya Bahan Baku & $\mathrm{Rp}$ & 40.800 .000 \\
\cline { 2 - 4 } & Biaya Tenaga Kerja & $\mathrm{Rp}$ & 19.800 .000 \\
\cline { 2 - 4 } & Biaya Operasional & $\mathrm{Rp}$ & 1.900 .000 \\
\cline { 2 - 4 } & Jumlah & $\mathbf{R p}$ & $\mathbf{1 5 3 . 0 0 0 . 0 0 0}$ \\
\hline
\end{tabular}

Proyeksi Laba Rugi

\begin{tabular}{|c|c|c|c|c|c|c|}
\hline Komponen & \multicolumn{2}{|r|}{ Tahun 1} & \multicolumn{2}{|r|}{ Tahun 2} & \multicolumn{2}{|r|}{ Tahun 3} \\
\hline Penjualan & $\mathrm{Rp}$ & \begin{tabular}{l|l}
835.200 .000 \\
\end{tabular} & $\mathrm{Rp}$ & 1.814 .400 .000 & $\mathrm{Rp}$ & 3.135 .600 .000 \\
\hline \multicolumn{7}{|l|}{ Biaya Variabel } \\
\hline Biaya Produksi & $\mathrm{Rp}$ & 489.600 .000 & $\mathrm{Rp}$ & 1.054 .080 .000 & $\mathrm{Rp}$ & 1.843 .920 .000 \\
\hline \begin{tabular}{|l|} 
Margin Kotor \\
\end{tabular} & Rp & 345.600 .000 & $\mathbf{R p}$ & 760.320 .000 & $\mathbf{R p}$ & 1.291 .680 .000 \\
\hline \multicolumn{7}{|l|}{ Biaya Tetap } \\
\hline Sewa Outlet & $\mathrm{Rp}$ & - & $\mathrm{Rp}$ & 36.000 .000 & $\mathrm{Rp}$ & 72.000 .000 \\
\hline Gaji Pegawai & $\mathrm{Rp}$ & 237.600 .000 & $\mathrm{Rp}$ & 361.800 .000 & $\mathrm{Rp}$ & 670.080 .000 \\
\hline Internet & $\mathrm{Rp}$ & 2.400 .000 & $\mathrm{Rp}$ & 3.000 .000 & $\mathrm{Rp}$ & 3.600 .000 \\
\hline Pulsa & $\mathrm{Rp}$ & \begin{tabular}{l|l}
3.600 .000 \\
\end{tabular} & $\mathrm{Rp}$ & 6.000 .000 & $\mathrm{Rp}$ & 8.400 .000 \\
\hline Listrik & $\mathrm{Rp}$ & 2.400 .000 & $\mathrm{Rp}$ & 3.000 .000 & $\mathrm{Rp}$ & 3.600 .000 \\
\hline Telepon & $\mathrm{Rp}$ & 2.400 .000 & $\mathrm{Rp}$ & 3.000 .000 & $\mathrm{Rp}$ & 3.600 .000 \\
\hline Promosi & $\mathrm{Rp}$ & 12.000 .000 & $\mathrm{Rp}$ & 18.000 .000 & $\mathrm{Rp}$ & 30.000 .000 \\
\hline Perawatan & $\mathrm{Rp}$ & 600.000 & $\mathrm{Rp}$ & 1.320 .000 & $\mathrm{Rp}$ & 2.280 .000 \\
\hline Penyusutan & $\mathrm{Rp}$ & \begin{tabular}{|l|l}
5.833 .333 \\
\end{tabular} & $\mathrm{Rp}$ & 6.633 .333 & $\mathrm{Rp}$ & 7.433 .333 \\
\hline Total Biaya Tetap & Rp & 266.833.333 & Rp & 438.753.333 & Rp & 800.993 .333 \\
\hline Laba Kotor & $\mathrm{Rp}$ & 78.766 .667 & $\mathrm{Rp}$ & 321.566 .667 & $\mathrm{Rp}$ & 490.686 .667 \\
\hline Pajak 10\% & $\mathrm{Rp}$ & \begin{tabular}{l|l}
7.876 .667 &
\end{tabular} & $\mathrm{Rp}$ & 32.156 .667 & Rp & 49.068 .667 \\
\hline Laba Bersih & Rp & \begin{tabular}{l|l}
70.890 .000 \\
\end{tabular} & $\mathbf{R p}$ & 289.410 .000 & $\mathbf{R p}$ & 441.618 .000 \\
\hline \multicolumn{7}{|l|}{ Cash Flow } \\
\hline \multirow{2}{*}{ Uraian } & \multicolumn{6}{|c|}{ Tahun } \\
\hline & & $\mathbf{I}$ & & II & & III \\
\hline Sumber Dana (Inflow) & & Rp 835.200 .000 & & o 1.814 .400 .000 & $\mathrm{Rp}$ & 3.135 .600 .000 \\
\hline Penggunaan Dana (Outflow) & & Rp 764.310 .000 & & 1.524 .990 .000 & $\mathrm{Rp}$ & 2.693 .982 .000 \\
\hline Arus Kas Bersih (Netflow) & & Rp $\quad 70.890 .000$ & & 289.410 .000 & $\mathrm{Rp}$ & 441.618 .000 \\
\hline Keadaan Kas Awal & & $\mathrm{Rp}$ & $\mathrm{Rp}$ & 70.890 .000 & $\mathrm{Rp}$ & 360.300 .000 \\
\hline Keadaan Kas Akhir & & $\begin{array}{ll}\mathrm{Rp} & 70.890 .000\end{array}$ & \begin{tabular}{|l|l}
$\mathrm{Rp}$ \\
\end{tabular} & 360.300 .000 & $\mathrm{Rp}$ & 801.918 .000 \\
\hline
\end{tabular}

Kelayakan Investasi 


\begin{tabular}{|c|c|c|c|c|}
\hline Tahun & D.R (7\%) & Proceeds & \multicolumn{2}{|c|}{ PV dari Proceeds } \\
\hline 1 & 0,935 & Rp $\quad 70.890 .000$ & $\mathrm{Rp}$ & 66.282 .150 \\
\hline 2 & 0,873 & $\operatorname{Rp} 360.300 .000$ & $\mathrm{Rp}$ & 314.541 .900 \\
\hline 3 & 0,816 & Rp 801.918 .000 & $\mathrm{Rp}$ & 654.365 .088 \\
\hline \multicolumn{3}{|c|}{ Total PV } & $\mathbf{R p}$ & 1.035 .189 .138 \\
\hline \multicolumn{3}{|c|}{ Total Invetasi yang dikeluarkan } & Rp & 354.937 .500 \\
\hline \multicolumn{3}{|l|}{ NPV } & Rp & 680.251 .638 \\
\hline \multicolumn{3}{|l|}{ PI } & \multicolumn{2}{|r|}{2,92} \\
\hline
\end{tabular}

Payback Period:

Total Investasi yang dikeluarkan
Kas Tahun 1
Sisa
Kas Tahun 2

PBP $\frac{\operatorname{Rp} 284,047,500}{\operatorname{Rp} 360,300,000} \times 12$ bulan

Payback Period

9.46 Bulan

Jadi Nilai pengembalian untuk investasi di tas Sr Patron adalah selama 1 tahun 9 bulan.

\section{Kesimpulan dan Saran}

\subsection{Kesimpulan}

Dalam merancang dan menghasilkan tas yang dapat digunakan sebagai alas laptop (laptopper), yang dilakukan yaitu:

- Mengetahui kebutuhan konsumen, Kebutuhan konsumen dapat diketahui melalui observasi dan wawancara dengan menggunakan kuosioner. Dari observasi dan wawancara tersebut, diketahui kebutuhan konsumen seperti bentuk tas gendong (ransel), desain tas simpel dan elegan, bahan tas yang lembut, warna tas yang gelap, dan bahan alas laptop dari plastik.

- Membuat beberapa alternatif rancangan dengan menggunakan metode brainstorming, Dari brainstorming yang telah dilakukan, muncul 3 alternatif rancangan yang memenuhi kriteria kebutuhan konsumen.

- Menganalisa alternatif rancangan dengan metode Focuss Group Discussion (FGD) yang melibatkan responden, pengrajin tas, dan pengrajin plastik.

- Memilih salah satu alternatif tunggal berdasarkan hasil FGD dan mengembangkan spesifikasi terhadap produk yang terpilih. Alternatif yang terpilih seperti terlihat pada gambar 5.1

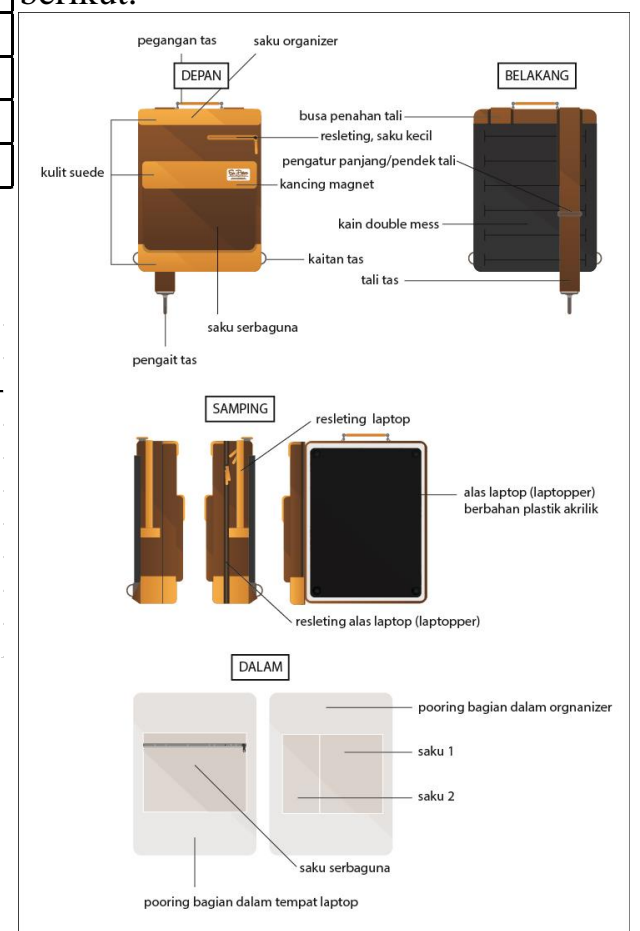

- Mempresentasikan hasil produk yang telah dikembangkan agar lebih menarik.

Perencanaan bisnis dari tas yang dapat digunakan sebagai alas laptop (laptopper) adalah sebagai berikut:

- Aspek Produk

Produk yang dihasilkan adalah tas inovatif yang dapat dijadikan alas laptop (laptopeer) sehingga dapat menjadi bantalan ketika memangku laptop.

- Aspek Pemasaran Aspek pemasaran menggunakan strategi STP (Segmenting, Targeting, Positioning) dan 7P (Product, Price, Place, Promotion, People, Process, Physical Evidence).

- Aspek Manajemen dan organisasi 


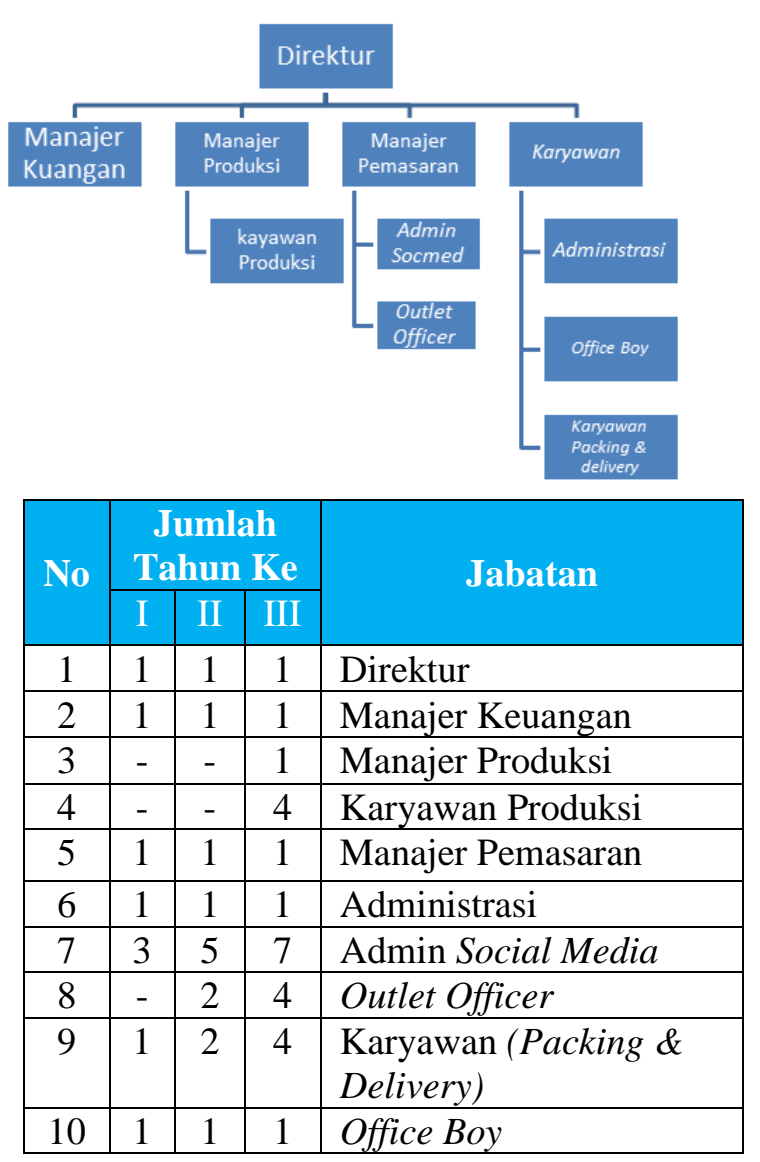

- Aspek Finansial

Bisnis tas ini layak, dengan perhitungan sebagai berikut:

a. Pada tahun ketiga, total Net Present Value (NPV) yang diperoleh adalah Rp 680.251.638,- Berdasarkan angka tersebut, maka bisnis bisa dikatakan layak. Hal tersebut karena NPV di tahun ketiga bernilai positif.

b. Profitable Index (PI) dari bisnis ini berada di angka 2,92. Hal tersebut berarti bisnis layak dijalankan, karena Index Profitabilitasnya lebih dari 1.

c. Payback Periode (PI) untuk bisnis ini adalah 1 tahun 9 bulan. Hal tersebut berarti Modal yang dikeluarkan untuk bisnis ini akan kembali di Tahun kedua pada bulan kedua dan hari pertama.

\subsection{Saran}

1. Bagi peneliti lebih lanjut,

Agar peneliti lebih lanjut dapat mengembangkan ilmu kewirausahaan yang dilandasi atas kreatifitas dan inovasi sehingga dapat menciptakan produk baru yang lebih inovarif yang sesuai dengan kebutuhan konsumen serta dapat diterima oleh konsumen. Selain itu, agar peneliti lain dapat melakukan market testing terhadap produk yang berhasil dibuat sebelum dijual ke konsumen.

2. Bagi Akademisi,

Agar dapat mengembangkan metode perencanaan bisnis yang didasari oleh konsep perancangan produk sehingga perencanaan bisnis yang disusun dapat lebih terarah dan sistematis.

3. Bagi Konsumen,

Agar konsumen dapat lebih sadar terhadap bebagai masalah yang ditimbulkan oleh kebiasaan memangku laptop serta dapat menggunakan tas inovatif yang dapat menghindari panas langsung yang diakibatkan oleh laptop sehingga konsumen menjadi lebih sehat dan nyaman ketika menggunakan laptop.

4. Bagi Investor,

Agar dapat memberikan investasi kepada produk yang inovasif terutama tas inovatif untuk mengatasi kebiasaan memangku laptop, serta dapat memberikan investasi pada perusahaan yang memiliki perencanaan bisnis yang matang. Sehingga visi dan misi perusahaan dapat dijabarkan melalui strategi yang diterapkan saat ini dan dimasa depan, perusahaan dapat menghasilkan profit yang besar bagi investor.

5. Bagi Pemerintah,

Agar pemerintah lebih sadar terhadap dampak yang ditimbulkan oleh kebiasaan menggunakan laptop diatas pangkuan, sehingga dapat mendukung produk inovatif ini dan dapat menciptakan kebijakan yang dapat 
mengurangi dampak dari memangku laptop

\section{Daftar Pustaka}

Anonymous. 2011. Pengertian Business Plan. (www.entrepreneurmuda.com. Diakses pada 23 Juli 2013)

Ginting, R. 2010. Perancangan Produk. Yogyakarta: Graha Ilmu.

Husein, U. 2000. Metolologi Penelitian: Aplikasi dalam Pemesaran. Jakarta: PT. Gramedia Pustaka Utama.

Kasmir. 2006. Kewirausahaan: Edisi Revisi. Jakarta: PT Raja Grafindo Persada.

Kashmir dan Jakfar. 2003. Studi Kelayakan Bisnis. Jakarta: Kencana Prenada Media Grup.

Kotler, P. dan Keller, K.L. 2009. Manajemen Pemasaran, Edisi Ketiga Belas: Jilid 2. Jakarta: Erlangga.

Legawa, Y. 2012. "Proses Perancangan Celana Berpembalut (Nalut”). Skripsi. Bandung: Fakultas Teknik, Universitas Komputer Indonesia.

Panuju, R. 2000. Komunikasi Bisnis, Bisnis Sebagai Proses Komunikasi, Komunikasi Sebagai Kegiatan Bisnis. Jakarta: Gramedia Pustaka Utama.

Rangkuti, F. 2000. Business Plan: Teknik Membuat Perencanaan Bisnis dan Analisis Kasus. Jakarta: Gramedia Pustaka Utama.

Riyanto, B. 1995. Dasar-Dasar Pembelajaran Perusahaan: Edisi Keempat. Yogyakarta: Yayasan Penerbit Gajah Mada.

Sekaran, U dan Bougie, R. 2010. Research Methods for Business: Fifth Edition. United Kingdom: John Wiley \& Sons Ltd.

Soegoto, E.S. 2009. Entrepreneurship: Menjadi Pebisnis Ulung. Jakarta: PT Elex Media Kompetindo.

Stenberg, R.J. 2006. The Nature of Creativity. Creativity Research Journal. Volume. 18, No. 1, Page 87-98. Sugiarto, E.C. 2013. Gerakan Kewirausahaan Nasional Untuk Menyebar Virus Wirausaha. (www.setkab.go.id/artikel-7434- gerakan-kewirausahaan-nasional-untukmenyebar-virus-wirausaha.html. Diakses pada 14 September 2013).

Supriyanto. 2009. Business Plan Sebagai

Langkah Awal Memulai Usaha. Jurnal Ekonomi dan Pendidikan, Volume 6 Nomor 1. Halaman 73-83.

Suryana, Y. dan Bayu, K. 2011. Kewirausahaan. Jakarta: Kencana Prenada Media Grup. 